\title{
The impact of Covid-19 on Western Balkans economies
}

ISSN 1857-9973

330.55]:616.98:578.834-036.21(497-15)

338]:616.98:578.834-036.21(497-15)

339.56]:616.98:578.834-036.21(497-15)

\section{Vesna Georgieva Svrtinov ${ }^{1}$, Olivera Gjorgieva Trajkovska², Emilija Miteva-Kacarski ${ }^{3}$ Blagica Koleva ${ }^{4}$}

${ }^{1}$ University Goce Delcev Stip, Faculty of Economics, vesna.svrtinov@ugd.edu.m

${ }^{2}$ University Goce Delcev Stip, Faculty of Economics, olivera.trajkovska@ugd.edu.mk

${ }^{3}$ University Goce Delcev Stip, Faculty of Economics,emilija.miteva@ugd.edu.mk

${ }^{4}$ University Goce Delcev Stip, Faculty of Economics,blagica.koleva@ugd.edu.mk

\section{Abstract}

Western Balkans, consisting of Bosnia and Herzegovina, Serbia, Kosovo, North Macedonia, Albania and Montenegro, is one of the regions that have been heavily affected by the Covid-19 pandemic. Although the numbers are relatively low compared to other countries affected by the virus, the region's fragile political and economic circumstance have made it vulnerable to the pandemic. The violent breakup of Yugoslavia continue to affect the region's international relations and domestic politics. Furthermore, Western Balkan states are some of the few European countries that are still not members of the European Union (EU) .

Every day, people are losing jobs and income, with no way of knowing when normality will return. The Western Balkans rely heavily on the steady inflow of remittances, which financing domestic demand and investment. Remittances, which constitute $10 \%$ of the GDP in these countries, are likely to diminish because of travel restrictions and increased unemployment in the countries of Western Europe. [1]. The World Bank projects a US\$110 billion decline in remittances this year, which could mean 800 million people will not be able to meet their basic needs [2]. Due to business shutdowns, supplyside disruptions, reduce household incomes, depress demand these countries results in fall in gross domestic product.

To mitigate the social impacts of the crisis, governments in all six countries have introduced measures to support households and businesses. To ease the effects of the pandemic, governments in the region have turned towards international institutions such as the World Bank, International Monetary Fund (IMF) and the EU for financial assistance. As these countries do not have sufficient health infrastructure to deal with a wide number of cases, these support have been useful to contain the spread of the virus.

Key words: Covid-19 virus, global health crisis, government response, recession Western Balkans 


\section{Introduction}

The coronavirus COVID-19 pandemic is global health crisis, unprecedent socio-economic crisis and the greatest challenge we have faced since World War Two. Since its emergence in Asia late last year, the virus has spread to almost every continent. All aspects of life, such as education, politics, public security, and economic activity, are being affected severely because of this global health threat. This crisis is an unprecedented shock that has taken the world and its economy by surprise.

Western Balkans was and still is seriously affected by this pandemic. These countries like other countries in Europe and the rest of the world, are projected to face recessions this year and maybe the following years. The duration of the recession for sure will depend on the duration of the pandemic. Also, all of these six countries will face different economic downturn depend of economic structure and pre-crisis vulnerabilities.

The Western Balkan economies are particularly affected through several channels.

The containment measures have an impact on domestic demand and supply, significantly decreasing economic activity. Due to depressed demand, exports across the region sharply decreased. A deceleration of both public and private investment negatively affect economic growth. A reduction in foreign direct investment inflows would also negatively affect job creation and technological progress in the future. Restrictions which was put on international travel lead to a collapse in tourism in summer season in Albania and Montenegro.

One of the biggest challenge that these countries will face is fall od remittances. As we already know the countries from Western Balkans rely heavily on the steady inflow of remittances, financing domestic demand and investment. Remittances, which constitute around $10 \%$ of the GDP on average, decline due to travel restrictions and increased unemployment, in Western European countries [2].

As a response of the consequences which may be coused by the pandemic Western Balkan countries have taken serious measures to stop the spread of the virus including: declaring a state of emergency, introducing curfew, closing borders, schools and businesses banning public gatherings etc.

In the first few months of the crisis, they have focused on strengthening public health systems, supporting firms to save jobs, and rapidly expanding programs that support the poor and the unemployed. Furthermore, governments introduced measures to protect their fragile health systems by purchasing medical equipment and medicine, increasing the salaries of medical staff etc. The EU, Russia, China and Turkey have also sent medical equipment to these countries in an effort to help them tackle the pandemic.

All WB countries have crisis response measures in place to cushion the demand effects on labor incomes and firm bankruptcies. In addition, governments took fiscal and social measures to support households and businesses during the emergency. These values are ranging from 1 to 7 percent of GDP, including budgetary support (see table 1)

Table 1. Budget support, Measures adopted by WB countries in billion euro

\begin{tabular}{|c|c|c|}
\hline Country & Total & \% of GDP \\
\hline Albania & 0,4 & 2,4 \\
\hline Bosina and Herzegovina & 0,4 & 2,3 \\
\hline Kosovo & 0,2 & 2,8 \\
\hline Montenegro & 0,05 & 1,0 \\
\hline North Macedonia & 0,2 & 2,0 \\
\hline Serbia & 3,2 & 6,7 \\
\hline
\end{tabular}

Source: World bank Group, calculations 
As we can see from the table above Serbia has the biggest budgetary support, and smallest support has Montenegro.

In this paper we will examines economic situations and challenges in all six countries of Western Balkan caused by the pandemic as well as the measures taken by the governments during this process.

\section{The impact of Corona crisis on the economies in separate Western Balkan countries and the undertaken policy measures}

In this part we will analyze the impact that WB countries have from the pandemic and which kind of measures were undertaken by their governments in order to mitigate the negative effects of the crisis on their economies.

\subsection{Albania}

According to IMF estimates, real GDP growth in Albania is expected to decline by $5 \%$ in 2020 from the estimated $2.2 \%$ growth in 2019 . The most affected sectors are tourism, transport and trade. In July 2020, the number of foreign tourists was found to have decreased by $61.5 \%$ compared to last year. It is expected that export will fall by $25-30 \%$ percent. This is especially due to diminish in export in Italy due to the fact that almost $50 \%$ of exports are directed to this country, as well as rapid decline of domestic demand for goods and services ( see graph 1)

Chart 1. Projected GDP growth rate 2016-2023

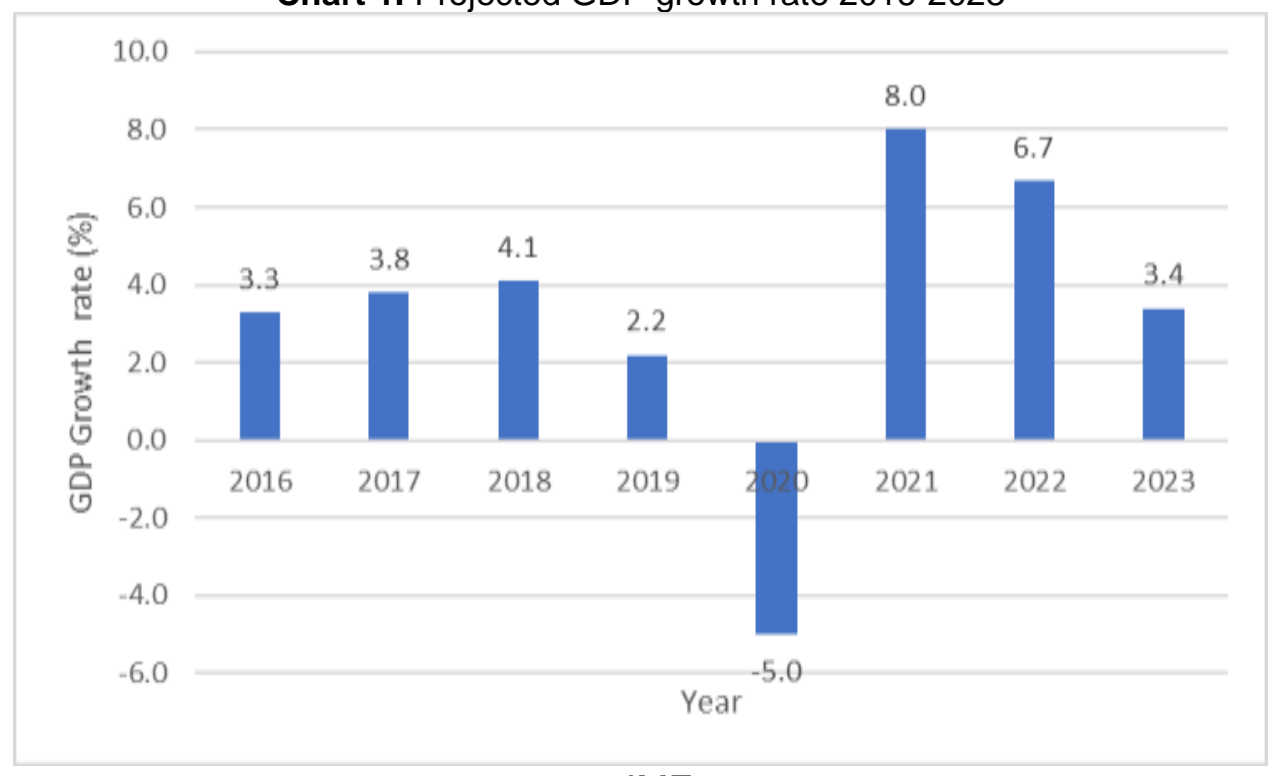

Source: IMF,2020

The Albanian currency, has depreciated by almost 7\% since the beginning of the COVID-19 crisis. This depreciation affected enterprises' ability to make payments denominated in foreign currency, which is a problem because of high percentage of foreign exchange denominated loans. The depreciation of Albanian national currency Lek against EUR and the strong increase 
in food prices caused the CPI inflation in Albania to pick up from 1.4\% in 2019 to $2.1 \%$ in March 2020, although still below the 3\% target. However, in August, CPI inflation fell again to 1.3\% compared to $1.4 \%$ the year before. [3].

The country undertake several monetary policy measures. As of 25 March, the Bank of Albania reduce the interest rate for the overnight lending facility from $1.9 \%$ to $0.9 \%$ and maintained the interest rate for the overnight deposit facility unchanged, at $0.1 \%$. The Bank of Albania has increased the operational capacities in order to guarantee the supply of the economy with currency and banknotes as well as to ensure the smooth functioning of the electronic payment system. Central bank of Albania has adopted the operational strategy of unlimited liquidity into the banking system [4].

Further more government undertake fiscal measures in order to support affected businesses. A total of USD 65 million was made available for the most vulnerable part of the population, for small businesses and for the potential unemployment due to the virus. Additional USD 100 million, was provide through the instrument of a sovereign guarantee, for companies that have difficulties in paying employee salaries. On 25 August, the Prime Minister announced a planned increase of around $40 \%$ in the wages of doctors and nurses by next year. [4]

Albania also receive international support. The country from the EU package financial assistant to support the Western Balkans receive EUR 4 million of immediate support for the health sector and EUR 46.7 million of support for the social and economic recovery. On April 10, the IMF approved USD 190.5 million financial assistance to Albania. Further more Albania receive USD 700.000 in health assistance from the USA to help prepare the response of the health sector to the COVID-19 pandemic Albania also receive aid for its health care system from Turkey, China, Switzerland, Norway, Hungary and the UNDP. [4]

\subsection{Bosnia and Herzegovina}

Bosnia and Herzegovina's economy is expected to drop to $-1.9 \%$ in 2020 due to the coronavirus outbreak. With the transport of goods and services significantly reduced, trade,tourism and transport are among the most affected sectors in $\mathrm{BiH}$. In addition, the COVID-19 pandemic poses a major challenge to the manufacturing sector, (due to decline in supply from China and decline in deliveries of the textile and leather to Italy).

Statistic agency of BIH estimate a decline in second quarter of 2020 spending of EUR 454,6 million that leads to decline in GDP of EUR 859,7 million. Ultimately, the expected decline in GDP for 2020 on an annual basis is $6.34 \%$ (see table 2)

Table 2. GDP Projections for BIH

\begin{tabular}{|c|c|c|c|}
\hline Period & & $\begin{array}{c}\text { Household } \\
\text { Consumption } \\
\text { (000EUR) }\end{array}$ & GDP (000 EUR) \\
\hline \multirow{5}{*}{2019} & Q1 & 3.243 .513 & 4.325 .173 \\
\cline { 2 - 4 } & Q2 & 3.409 .883 & 4.584 .418 \\
\cline { 2 - 4 } & Q3 & 3.543 .606 & 4.783 .294 \\
\cline { 2 - 4 } & Q4 & 3.454 .946 & 4.575 .315 \\
\cline { 2 - 4 } & Total & $\mathbf{1 3 . 6 5 1 . 9 4 8}$ & $\mathbf{1 8 . 2 6 8 . 2 0 0}$ \\
\hline \multirow{3}{*}{2020} & Q1 & 3.243 .513 & 4.325 .173 \\
\cline { 2 - 4 } & Q2 & 2.955 .232 & 3.724 .690 \\
\hline
\end{tabular}




\begin{tabular}{|l|c|c|c|}
\hline \multirow{4}{*}{} & Q3 & 3.366 .425 & 4.485 .233 \\
\cline { 2 - 4 } & Q4 & 3.454 .946 & 4.575 .315 \\
\cline { 2 - 4 } & Total & $\mathbf{1 3 . 0 2 0 . 1 1 6}$ & $\mathbf{1 7 . 1 1 0 . 4 1 1}$ \\
\hline
\end{tabular}

Source OECD, 2020

Government have allocated around BAM 50 million (around EUR 25 million or $0.15 \%$ of GDP) for dealing with COVID-19, including purchasing medical equipment and supplies. The Federation of $\mathrm{BIH}$ reserved support of BAM 30 million (around EUR 15 million or $0.1 \%$ of GDP) to hospitals. In Republika Srpska, the health fund have covered health care costs for all patients.

Bosnia and Herzegovina will be getting $\$ 361$ million emergency support package from the IMF. The EU has also stepped in to help the country recover its economy by announcing a $€ 250$ million macro-financial assistance package [5] [6].

\subsection{Kosovo}

Like in the other countries of Western Balkan the COVID-19 pandemic and associated measures may cause an economic recession in Kosovo, especially because this economy is heavily reliant on remittances (arround 15\% of the GDP). Kosovo is one of the poorest European countries and its economy is expected to shrink between 2 and 4 per cent in 2020 as a result of the pandemic. Likewise, domestic demand falls and lead on increased levels of unemployment []

In this context is important to underline that Kosovo has unilaterally abandoned independent monetary policy to adopt the Euro as its national currency, and because of that is unable to make full use of typical monetary policy tools. The economy is therefore dependent on the monetary decisions taken at the EU level. In this context is important to underline that as the country is unilaterally euroized there is no effect on exchange rates.

One of the measures which was taken in order to relief the consequences of this crisis is that the Central Bank has suspended loan repayments for individuals and businesses until at least 30 April 2020. The interest rate on loans for SMEs operating in the tourism sector has been cut by $50 \%$, while the interest rate on loans for large companies has been cut by $15 \%$. Likewise, the reserve capital has been increased to enable firms affected by the crisis to access support instruments, such as credit guarantees and loans.

On 11 March, the government allocated EUR 10 million to fund efforts to contain the spread of the virus and reinforce the healthcare system. On 30 March, the government passed a major emergency support package of about EUR 170.6 million (3\% of GDP) to support individuals, firms, and municipalities affected by the COVID-19 crisis [6].

The government in the following months has continued to implement the Economic Recovery Programme, and allocated EUR 365 million in funds to support businesses, create jobs and stimulate aggregate demand. The most important measures from this Programme are the followings: the government allocated EUR 67 million to achieve its commitment to increase employment, with a specific focus on groups of workers with a lower probability of finding employment during the crisis; firms can receive subsidies covering $50 \%$ of their rental expenses; the plan allocates EUR 15 million to ease the tax burden on firms to improve their short-term liquidity; tax obligations for specific firms will be postponed or cancelled, penalties for late tax payments due to the pandemic have been removed, and the government will cover $5 \%$ of pension contributions. 
On the other hand, Kosovo will be benefiting from international financial assistance. The Millennium Challenge Corporation of the US allocated $\$ 50$ million to its programs in Kosovo. Moreover, the IMF allocated $\$ 57$ million to Pristina under the framework of pandemic emergency support. Kosovo will also be receiving up to $€ 100$ million from the EU's macrofinancial assistance package [7].

\subsection{Montenegro}

Montenegro heavily relies on tourism and remittances which are $10.7 \%$ of the GDP which coming from EU countries such as: Austria, Germany and Italy. Tourism sector's direct contribution to the economy accounts for $11.7 \%$ of the GDP, while indirect contributions of tourism to the economy accounts around $25 \%$ of the GDP. Taking this into account is more than obviously that the country will be affected by recession.

In addition, we present the main features of the Montenegro economy. For comparison we use years from 2016-2019.

Table 3. Main features of the economy (forecasting for 2020 and 2021) annual \% change

\begin{tabular}{|c|c|c|c|c|c|c|}
\hline GDP & 2016 & 2017 & 2018 & 2019 & 2020 & 2021 \\
\hline $\begin{array}{c}\text { Private } \\
\text { consumption }\end{array}$ & 2.9 & 4.7 & 5.1 & 3.6 & -5.9 & 4.4 \\
\hline $\begin{array}{c}\text { Public } \\
\text { consumption }\end{array}$ & 0.8 & -1.4 & 6.3 & 1.5 & 2.5 & -1.7 \\
\hline $\begin{array}{c}\text { Exports (goods } \\
\text { and services) }\end{array}$ & 5.9 & 1.8 & 6.9 & 6.4 & -33.7 & 24.3 \\
\hline $\begin{array}{c}\text { Import (goods } \\
\text { and services) }\end{array}$ & 16.3 & 8.4 & 9.2 & 2.1 & -26.1 & 16.0 \\
\hline $\begin{array}{c}\text { Unemployment } \\
\text { rate }\end{array}$ & 17.7 & 16.1 & 15.5 & 15.4 & 17.0 & 16.2 \\
\hline
\end{tabular}

Source: OECD,2020

As we can see from the table above, GDP rapidly decrease in 2020, due to decrease of private consumption. A swift recovery of the economy in 2021, while possible, is subject to very substantial uncertainties. Sharp decrease we noticed in export, which mainly is consequence of fall in tourism during the summer period. It is supposed that Montenegro will filed deeper recession from the corona crisis than from the global financial crisis. The main transmission channel is the collapse in tourism arrivals due to the breakdown of international travel following the lockdown measures implemented in many countries. Travel and tourism accounts for some $25 \%$ of Montenegro's GDP in total. The import is also decrease, because of the less domestically demand for goods and services. Unemployment rate increase for $1.6 \%$ compared to the previous year.

The central bank announced a moratorium on loan repayment for a period of up to 90 days. It includes the temporary suspension of all payments of obligations based on the loan. Banks are also allowed to restructure loans and reclassify them as new loans, including by additionally extending the repayment period by up to two years, if the borrower's financial position was

\footnotetext{
${ }^{1}$ As a $\%$ of total labour force
} 
impacted by the pandemic and restructuring would improve the credit capacity of the borrower. Low-interest credits are also provided to the enterprises.

The central bank has also announced measures to temporarily prohibit banks from paying dividends to shareholders, except in the form of equity.

Montenegro, which is a candidate country for the $E U$, will receive a $€ 60$ million from Brussels as part of the EU's macro-financial assistance package. On June 24, 2020, country received an emergency loan worth $\$ 83.7$ million under the IMF's Rapid Financing Instrument to help its economy weather the economic disruption caused by the collapse of tourism and to support higher health spending. [8]

\subsection{North Macedonia}

Measures to prevent the spread of COVID-19 have slowed economic activity, also in the North Macedonia. As of 20 March, a sharp decline of tax revenues by around $25 \%$ per day was observed. This translated into a decline of total tax revenues by $11 \%$ in March as compared to the previous year. This is a result of a17\% drop in VAT revenues, $11 \%$ in excise revenues and $11 \%$ in profit tax revenues. This has negative impact on the budget.

MBI10 index lost around 9\% of its value from 10 January to 14 April. The local currency "MKD" has depreciated around 3\% since the beginning of the year, signaling a potential capital outflow and rendering international trade and investment decisions more difficult.

The number unemployment residents from January until August (the last month that we have data) are constantly rising. See Graph

Chart 2. Unemployment residents in the period January-August 2020

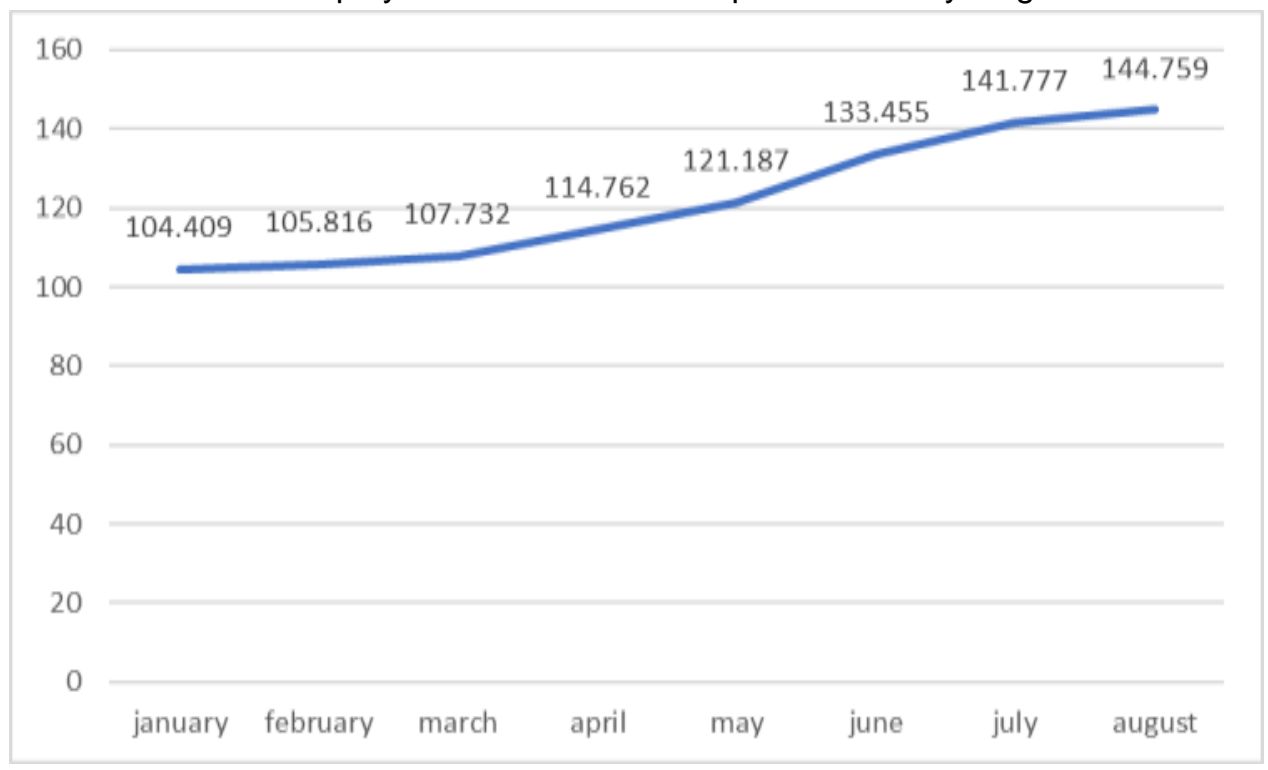

Source: Employment agency of North Macedonia, authors calculations

Exports from the country also contract due to weak global demand. The disruptions in global supply chains - as evidenced by cancelled and delayed orders - will lead to an expected fall of exports of goods and services. Based on more recent projections, the National Bank (May 2020) forecasts a fall of exports of goods and services of $17.1 \%$ in real terms. 
Due to the crisis in the countries which are main investors in North Macedonia, foreign direct investment also decrease.

Chart 3. Export of goods and services in the first half of 2020 compared to first half of 2019

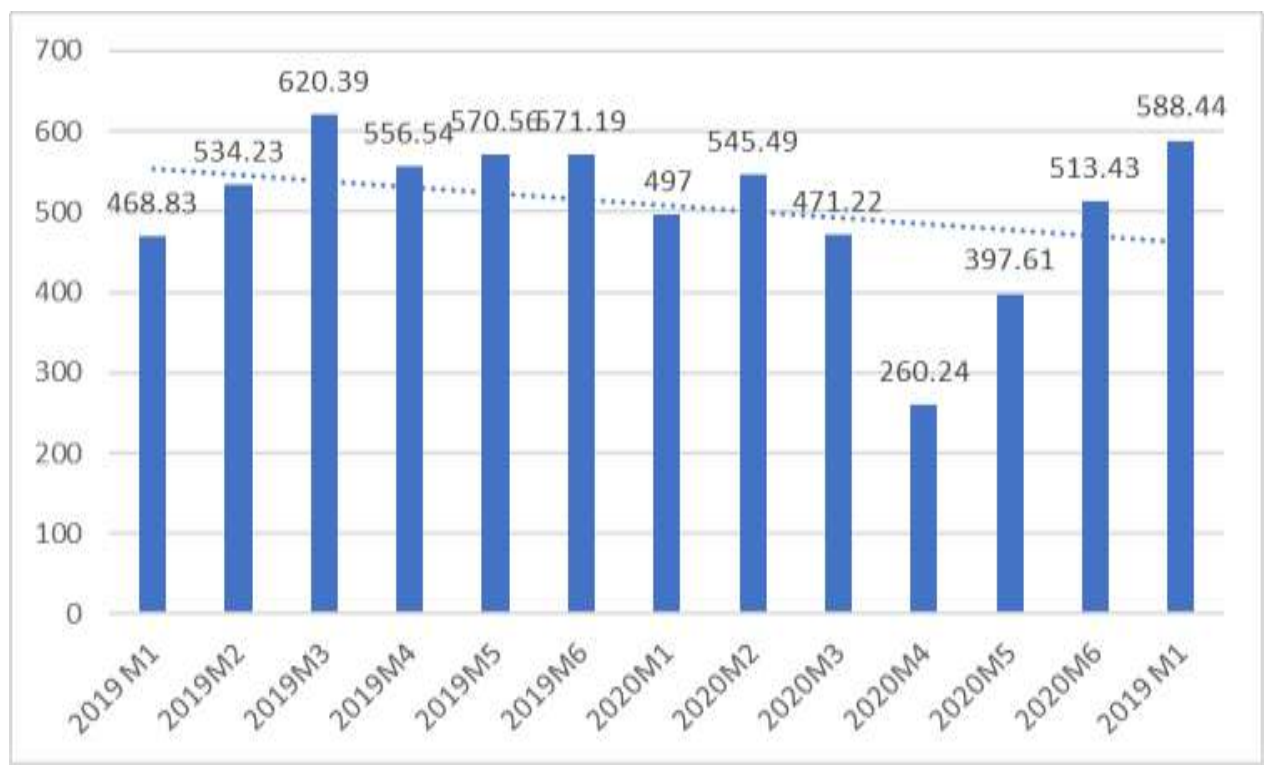

Source NBRM https://www.nbrm.mk/ns-newsarticle-kvartalen-izvestaj-statisticki-prilog-I2020.nspx

Chart 4. Inflows of FDI in the first half of 2020 compared to first half of 2019

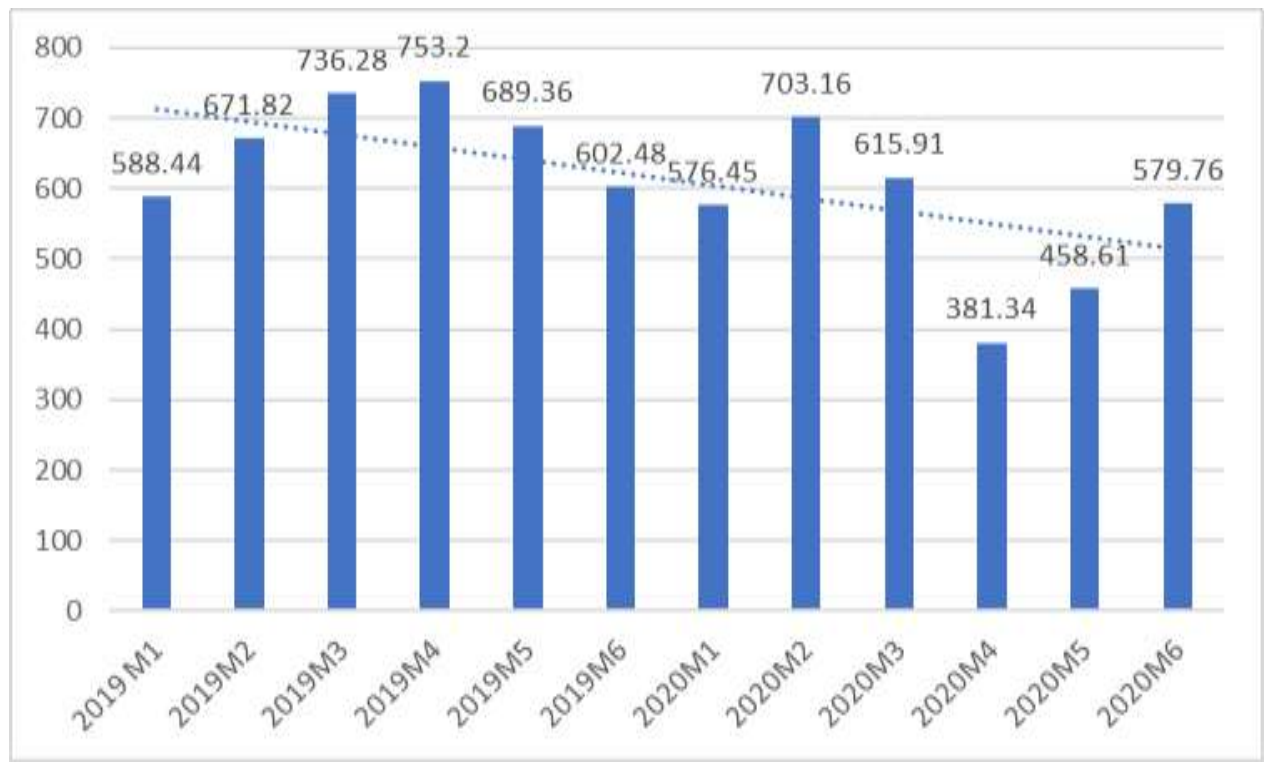

Source NBRNM, 2020

From the charts above we can notice decline in exports of goods and services as well as decrease of inflows of foreign direct investment in the first half of 2020 ( the period that we have available data) compared with the same period of 2019.The Development Bank of North 
Macedonia also introduced a series of interest-free loans to small and medium businesses to soften the pandemic's impact [9].

On 27 September 2020, the Government announced the launch of the 4th package of measures aimed at mitigating the negative impact of the pandemic on the economy. This package (whose estimated cost is EUR 470 million), taken as a direct extension of the three previous ones, will bring North Macedonia's aid up to EUR 1 billion.

The IMF approved the disbursement of EUR 176.53 million in emergency financial assistance to North Macedonia to help it cope with the COVID-19 pandemic. This financial support will help finance the health and macroeconomic stabilization measures, meet the urgent balance of payments needs arising from the COVID-19 pandemic and catalyze support from the international community.

The Commission on behalf of the EU has signed a Memorandum of Understanding (MoU) with North Macedonia to pave the way for the disbursement of $€ 80$ million in macro-financial assistance (MFA) [10].

\subsection{Serbia}

Serbia was in a moderate position prior to the COVID-19 outbreak. In 2019, the economy experienced a real GDP growth of $4.2 \%$. Unemployment was at its lowest level in the last decade, at $10.4 \%$. Currently, the Serbian economy is dealing with a COVID-19 related recession. According to the State Statistical Office (SORS), in the second quarter of the year, the national GDP decreased by $9.2 \%$.

The negative effect of the pandemic has been reflected in a drop in economic activity, with manufacturing, transportation and tourism being the most affected industries.

BELEX15 index lost around $20 \%$ of its value from 10 January to 14 April. The government bond spread increased by $6.2 \%$ between 1 January and 31 March. The local currency "RSD" has depreciated around 3\% since the beginning of the year, signaling a potential capital outflow and rendering international trade and investment decisions more difficult.

The Serbian government announced that it has enough financial reserves and that it would not apply to IMF financial aid program. On the other hand, Serbia is in talks with the World Bank for a $\$ 100$ million and Council of Europe Development Bank for a $€ 200$ million loan. The government announced a $€ 5.1$ billion assistance program to businesses effected from the pandemic and will make $a € 100$ one-time payment to all citizens aged 18 and over[11].

\section{How would the economies of the Western Balkans have faced the crisis without government and international support?}

In this section we compare how the economies of the Western Balkans would face the crisis without financial support from the government and international institutions. First, we analyze whether poverty would increase without such support.

Without carefully designed policy responses, the COVID 19 crisis could push a large share of vulnerable people into poverty. See chart below 
Chart 5. Simulated impact of the Covid -19 crisis without policy responses

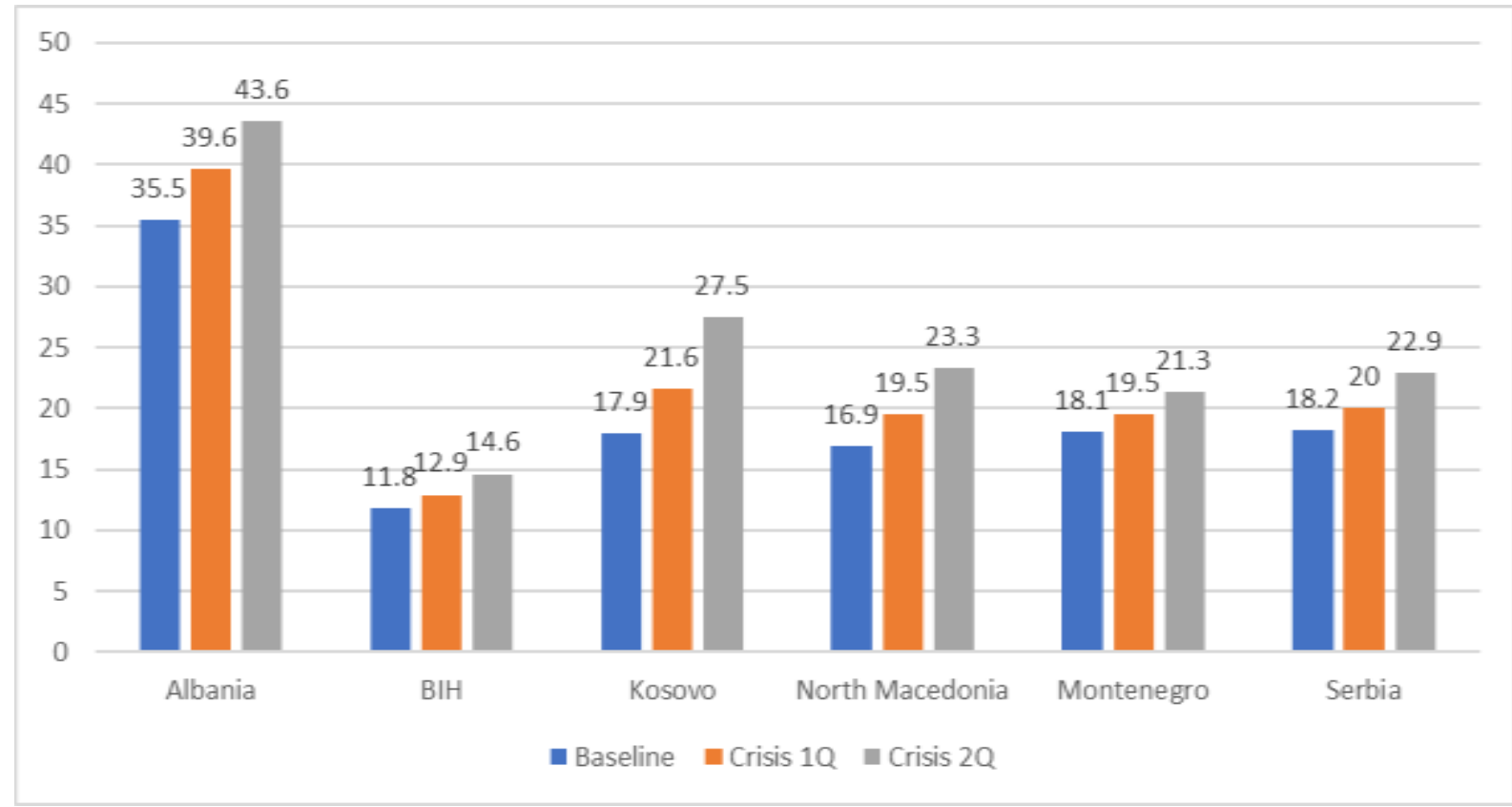

Source OECD,2020

As we can see from the chart above all Western Balkan countries would faced bigger negative impact of the Covid-19 crisis if there was no appropriate policy response

\section{Different scenarios of the main economic variables in Western Balkan countries due to Covid -19 crisis}

World bank made calculation of real GDP growth, consumption, investment, export and import in the Western Balkans using two scenario: baseline and downside, and compare them with the same variable in the pre crisis period. The data are given in the table below

Table 4. Pre Covid, Baseline and Downside scenario of economic variables in WB countries

\begin{tabular}{|c|c|c|c|c|c|c|c|c|c|}
\hline & \multicolumn{4}{|c|}{ Albania } & \multicolumn{3}{c|}{ BIH } & \multicolumn{3}{c|}{ Kosovo } \\
\hline & $\begin{array}{c}\text { Pre } \\
\text { Covid- } \\
19\end{array}$ & $\begin{array}{c}\text { Baseline } \\
\text { Scenario }\end{array}$ & $\begin{array}{c}\text { Downside } \\
\text { Scenario }\end{array}$ & $\begin{array}{c}\text { Pre } \\
\text { Covid- } \\
19\end{array}$ & $\begin{array}{c}\text { Baseline } \\
\text { Scenario }\end{array}$ & $\begin{array}{c}\text { Downside } \\
\text { Scenario }\end{array}$ & $\begin{array}{c}\text { Pre } \\
\text { Covid- } \\
19\end{array}$ & $\begin{array}{c}\text { Baseline } \\
\text { Scenario }\end{array}$ & $\begin{array}{c}\text { Downside } \\
\text { Scenario }\end{array}$ \\
\hline $\begin{array}{c}\text { Real GDP } \\
\text { growth }\end{array}$ & 3.3 & -5 & -6.2 & 3.4 & -3.2 & -4.2 & 4.1 & -4.5 & -11.3 \\
\hline Consumption & 3.1 & -1.6 & -2.2 & 3.3 & -2.7 & -3.8 & 3.2 & 1.1 & -0.6 \\
\hline Investment & 7.7 & 1 & 0.8 & 1 & -6.2 & -7.1 & 3.8 & -21.5 & -28.5 \\
\hline Exports & 2.7 & -25 & -30 & 3 & -8.8 & -10 & 4 & -12.2 & -25.5 \\
\hline Imports & 4.6 & -9.5 & -10.6 & 5 & -6.5 & -7.5 & 2.2 & -6.8 & -8 \\
\hline & \multicolumn{7}{|c|}{ Montenegro } & \multicolumn{7}{|c|}{ North Macedonia } & \multicolumn{3}{|c|}{ Serbia } \\
\hline & $\begin{array}{c}\text { Pre } \\
\text { Covid- } \\
19\end{array}$ & $\begin{array}{c}\text { Baseline } \\
\text { Scenario }\end{array}$ & $\begin{array}{c}\text { Downside } \\
\text { Scenario }\end{array}$ & $\begin{array}{c}\text { Pre } \\
\text { Covid- } \\
19\end{array}$ & $\begin{array}{c}\text { Baseline } \\
\text { Scenario }\end{array}$ & $\begin{array}{c}\text { Downside } \\
\text { Scenario }\end{array}$ & $\begin{array}{c}\text { Pre } \\
\text { Covid- } \\
19\end{array}$ & $\begin{array}{c}\text { Baseline } \\
\text { Scenario }\end{array}$ & $\begin{array}{c}\text { Downside } \\
\text { Scenario }\end{array}$ \\
\hline $\begin{array}{c}\text { Real GDP } \\
\text { growth }\end{array}$ & 3.2 & -5.6 & -8.9 & 3.6 & -1.4 & -3.2 & 3.9 & -2.5 & -5.3 \\
\hline Consumption & 2.9 & -3.6 & -4.8 & 4.3 & 0.6 & -0.3 & 5.7 & -2.3 & -3.5 \\
\hline
\end{tabular}




\begin{tabular}{|c|c|c|c|c|c|c|c|c|c|}
\hline Investment & 0 & -8.8 & -13.7 & 8 & -0.4 & -2.7 & 5.3 & -5.2 & -7.7 \\
\hline Exports & 4.1 & -18.5 & -27.8 & 7.4 & -0.2 & -2.9 & 4.9 & -10.2 & -18.5 \\
\hline Imports & 1.9 & -12.4 & -17.7 & 9.4 & 1.9 & 0.1 & 7.6 & -9.7 & -15.1 \\
\hline & & & & & & & & & \\
\hline
\end{tabular}

Source: World Bank Group, staff calculations,2020

The worst projections are for Kosovo, which in the case of a more favorable scenario expects a decline in GDP of 4.5 per cent, and in the case of more unfavorable development of the situation, that decline would amount to as much as 11.3 per cent. Similar forecasts apply to Montenegro, which in the event of a rapid halt to the spread of coronavirus expects an economic decline of 5.6 per cent, and in the event of a continuation of the pandemic the decline would be as much as 8.9 per cent. The projections for Albania are also on that track, where they can count on a 5 or 6.9 per cent drop in GDP. Bosnia and Herzegovina, which is projected to fall by 3.2 per cent and 4.2 per cent, is somewhat better off. Serbia would face a negative rate of 2.5 and 5.3 per cent, respectively, and the least damage would be suffered by Northern Macedonia, whose economy is estimated to fall by 1.4 to 3.2 per cent.

The biggest fall in the consumption is estimated in Montenegro in two scenarios, and the smallest fall in North Macedonia. The investments will decrease the most in Kosovo, followed by Montenegro, while in Albania they decline compared to pre crisis period, but remain positive. The biggest fall in export faced Albania, Montenegro, due to decrease in tourism during the summer period, as well as Kosovo. In all countries import in the two scenarios noticed negative number, except in North Macedonia, however smaller than the pre Covid period [12].

\section{Summary}

In the first half of 2020, the world has seen explosive growth of infections with the deadly novel virus. Country after country has been forced to shut down large areas of social and economic life to slow contagion. Like many other countries Western Balkans have not been spared as well.

In response, all six countries of WB have enforced strict social distancing measures. International airports in all countries were closed for passenger traffic. Travel and social gatherings have been restricted or banned, and schools and universities have been closed.

The COVID-19 crisis has severe consequences for the economies of the these countries. Both, aggregate supply and aggregate demand declined rapidly. Declining economic activity is also complicating public finances and expanding the financing needs of governments. Furthermore, the summer tourism also declined. Nonessential consumption and investment are delayed until the uncertainty linked to the crisis is resolved.

Western Balkan countries have announced sizable fiscal packages ranging from 1 to 7 percent of GDP to support their citizens and businesses.

According to study made by World bank many jobs will be cut in the Western Balkans and at least 400,000 people could fall into poverty, with the middle class being the hardest hit. Its important to underline that many jobs in these countries are temporary or they are in the informal sector. As the COVID-19 crisis develops, it is likely that these jobs will be most affected by the closure. Worst of all, many of these workers may not be able to used their social security rights.

We may conclude that Corona crisis will have severe consequences for the economies of the Western Balkans and that recovery will depend on measures taken by the authorities. It is very 
important challenge for governments to manage liquidity closely to avoid further escalation of the crisis, while providing assistance to those most in need.

\section{References}

[1] OECD, The covid 19 crisis in the Western Balkans, Economic impact, policy responses and short term sustainable solution, 2020, http://www.oecd.org/south-east-europe/COVID-19-CrisisResponse-Western-Balkans.pdf

[2] (World Bank, Bank The economic and social impact of covid-19, Western Balkans regular $\begin{array}{llll}\text { economic } & \text { report, } & \text { No.17, } & \text { Spring }\end{array}$ https://www.worldbank.org/en/region/eca/publication/western-balkans-regular-economic-report

[3] IMF, Country Report, No. 20/18 Albania request for purchase under the rapid financing instrument-press release; staff report; and statement by the executive director for Albania,2020, https://www.imf.org/en/Publications/CR/Issues/2020/04/17/Albania-Request-forPurchase-under-the-Rapid-Financing-Instrument-Press-Release-Staff-Report-49347

[4] World OECD, OECD Tacking Corona Virus (Covid 19) Contributing to an global efford, The Covid-19 crisis in Albania, October 1 st , 2020 https://www.oecd.org/south-east-europe/COVID19-Crisis-in-Albania.pdf

[5] OECD Tacking Corona Virus (Covid 19) Contributing to an global efford, The Covid-19 crisis in Bosnia-and-Herzegovina, October 1 st , 2020https://www.oecd.org/south-easteurope/COVID-19-Crisis-in-Bosnia-and-Herzegovina.pdf

[6] IMF, Press Release, No. 20/176. IMF Executive Board Approves US\$361 Million in Emergency Support to Bosnia and Herzegovina to Address the COVID-19 Pandemic https://www.imf.org/en/News/Articles/2020/04/20/pr20176-bosnia-and-herzegovina-imf-

executive-board-approves-usd361-million-in-emergency-support

[7] OECD, The Covid - 19 crisis in Kosovo, October, 2020, https://www.oecd.org/south-easteurope/COVID-19-Crisis-in-Kosovo.pdf

[7] IMF, Press Release, IMF Executive Board Approves US\$56.5 Million in Emergency Support to the Republic of Kosovo to Address the COVID-19 Pandemic No. 20/176 https://www.imf.org/en/News/Articles/2020/04/10/pr20149-kosovo-imf-executive-boardapproves-us-million-emergency-support-address-covid-19-pandemic

[8] European Economy Policy, Montenegro, Spring, 2020 https://ec.europa.eu/economy_finance/forecasts/2020/spring/ecfin_forecast_spring_2020_me_e n.pdf

[9] National Bank of the Republic of North Macedonia database, kvartalen izvestaj, 2020, https://www.nbrm.mk/ns-newsarticle-kvartalen-izvestaj-statisticki-prilog-l-2020.nspx

[10] European Commission Coronavirus: Macro-financial assistance agreement provides for $€ 80$ million disbursement to North Macedonia, July, Brussels, https://ec.europa.eu/commission/presscorner/detail/en/IP_20_1343

[11] European Commission, COVID-19: impact on the Serbian economy and the government recovery package, ESPN Flash Report 2020/4

[12] World Bank Group Western Balkans Regular Economic Report, No. 17, Spring 2020 : The Economic and Social Impact of COVID-19 